\title{
Stability-Indicating RP-HPLC Method for Analysis of Paracetamol and Tramadol in a Pharmaceutical Dosage Form
}

\author{
RAJESH M. KAMBLE* AND SHRAWAN G. SINGH \\ Department of Chemistry, University of Mumbai, Vidyanagari, \\ Santacruz (East), Mumbai- 400 098, (MS), India \\ chemrajkam@yahoo.co.in
}

Received 19 October 2011; Accepted 30 December 2011

\begin{abstract}
A simple, isocratic, rapid and accurate reversed phase high performance liquid chromatography method was developed for the quantitative determination of paracetamol and tramadol in commercial medicinal tablets. The chromatographic separation was achieved on an Inertsil $\mathrm{C}_{18}(250 \mathrm{~mm} \times 4.6$ $\mathrm{mm}, 5 \mu \mathrm{m})$ column using water $\mathrm{pH} 3.4$ with orthophosphoric acid: methanol $(60: 40, \mathrm{v} / \mathrm{v})$ as a mobile phase, and UV detection at $228 \mathrm{~nm}$. The chromatographic resolutions between paracetamol and tramadol were found greater than five. The linear range for paracetamol and tramadol were $20.8-39.0 \mu \mathrm{g} / \mathrm{ml}$ and $2.4-4.5 \mu \mathrm{g} / \mathrm{ml}$ was obtained with correlation coefficients $\geq 0.999$ for each analyte. The retention time were found to be 2.1 and $3.9 \mathrm{~min}$ for tramadol and paracetamol respectively. Paracetamol and tramadol was subjected to stress conditions (hydrolysis (acid, base) oxidation, photolysis and thermal degradation) and the stressed samples were analyzed by use of the method. The major degradation was observed in acid and minor in base, thermal, oxidation and photolysis. The forced degradation studies prove the stability indicating power of the method.
\end{abstract}

Keywords: Paracetamol, Tramadol, RP-HPLC, Validation, Stress studies.

\section{Introduction}

In recent times there has been an increased tendency toward development of stabilityindicating assays ${ }^{1-3}$, using the approach to stress testing enshrined in International conference on harmonization (ICH) guideline Q1A (R2) ${ }^{4}$. This approach is being extended to drug combinations to enable accurate and precise quantification of several drugs in the presence of their degradation products. Paracetamol is chemically 4-hydroxy acetanilide (Figure 1). It is a weak inhibitor of peripheral cyclooxygenase and its analgesic effects may arise from inhibition of prostanoid synthesis in the CNS. The antipyretic effects of paracetamol are due to its action at the level of the hypothalamus to reduce pyrogen-initiated 
alterations in body temperature by inhibiting prostaglandin synthesis ${ }^{5-6}$. Tramadol hydrochloric ( \pm )-cis-2-(dimethylamino) methyl-1-(3-methoxy-phenyl) cyclohexanol hydrochloride (Figure 1), a synthetic analogue of codeine, is a centrally acting analgesic agent $^{7}$. It has been used since 1977 for the relief of severe physical pain and has been the most widely sold opioid analgesic drug in the world ${ }^{8}$. There are many reported methods for analysis of tramadol ${ }^{9-13}$ or paracetamol ${ }^{14-17}$ either alone or in combination with other drugs $^{18-20}$ in pharmaceutical dosage forms. Very few reports are there on simultaneous estimation of paracetamol and tramadol. They were determined in human plasma samples using liquid chromatography (LC-MS $)^{21-22}$. In tablets they were estimated using spectrophotometry ${ }^{23-24}$ HPTLC $^{25-26}$, GC-MS $^{27}$ and HPLC $^{27-30}$ methods. Till date, to the best of our knowledge, no method has been reported in the literature for the stability indicating assay for these two compounds simultaneously. This manuscript describes the development and validation, in accordance with ICH guidelines, of rapid, economical, precise and accurate stability-indicating isocratic reversed-phase HPLC method for analysis of paracetamol and tramadol in the presence of its degradation products.<smiles>CC(=O)Nc1ccc(O)cc1</smiles>

Paracetamol

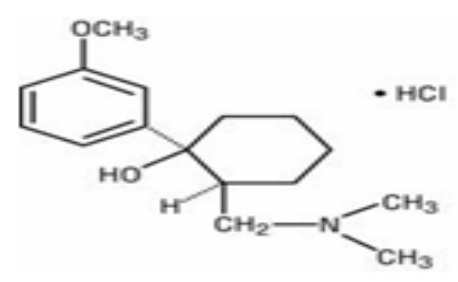

Tramadol $\mathrm{HCl}$

Figure 1. Structure of paracetamol and tramadol.

\section{Experimental}

\section{Chemicals and reagents}

Paracetamol and tramadol reference standards were obtained from sigma Aldrich, Acetonitrile, methanol, water (HPLC grade), orthophosphoric acid (AR) were obtained from Merck Ltd.

Stock solutions of paracetamol $(65 \mathrm{mg})$ and tramadol $(7.5 \mathrm{mg})$ were weighed independently and transferred separately to $100 \mathrm{ml}$ volumetric flask. The drug was dissolved in methanol and dilution was made to the mark. A mixed standard solution was prepared from above solution by dissolving $4.0 \mathrm{ml}$ of both stock solution in to $100 \mathrm{ml}$ volumetric flask and diluted up to the volume with mobile phase to get final concentration of 26.0 $\mu \mathrm{g} / \mathrm{ml}$ of paracetamol and $3.0 \mu \mathrm{g} / \mathrm{ml}$ of tramadol.

\section{Instrumentation and Chromatographic conditions}

An isocratic HPLC (Thermo Electron Corporation) with pump P-2000, UV/VIS-1000 was used. The analysis was carried out on Inertsil ODS $\mathrm{C}_{18}(250 \mathrm{~mm} \times 4.6 \mathrm{~mm}, 5 \mu \mathrm{m})$, a manual injector with a $20 \mu \mathrm{l}$ loop was used for the injection of sample solution and the mobile phase. 
Freshly prepared water adjusted $\mathrm{pH} 3.4$ with orthophosphoric acid and methanol in the ratio of $60: 40 \mathrm{v} / \mathrm{v}$ was used as mobile phase. These were filtered through $0.45 \mu \mathrm{m}$ membrane filter and sonicated before use. The flow rate of mobile phase was $1.0 \mathrm{ml} / \mathrm{min}$. The column was maintained at ambient temperature. The detection was carried out by at $228 \mathrm{~nm}$ and runtime was around $8 \mathrm{~min}$.

\section{Preparation of tablet solution}

Twenty tablets were accurately weighed and finely powdered. A quantity of powder equivalent to $65 \mathrm{mg}$ of paracetamol and $7.5 \mathrm{mg}$ of tramadol were transferred to $100 \mathrm{ml}$ volumetric flask and dissolved in methanol. The solution was filtered through Whatmann filter paper. From the above solution $4.0 \mathrm{ml}$ was taken and diluted to $100 \mathrm{ml}$ with mobile phase to give test solution containing $26.0 \mu \mathrm{g} / \mathrm{ml}$ of paracetamol and $3.0 \mu \mathrm{g} / \mathrm{ml}$ of tramadol. These sample solution were injected six different times.

\section{Results and Discussion}

\section{Optimization of chromatographic conditions}

The primary objective in developing the present stability-indicating HPLC method was to achieve resolution between paracetamol and tramadol and its degradation products. The choice of chromatographic conditions selected was based on symmetry of peak shape and reduction of chromatographic analysis. The mobile phase consisting of buffer (water adjusted to $\mathrm{pH} 3.4$ with orthophosphoric acid) and methanol in composition of $(60: 40 \mathrm{v} / \mathrm{v})$ was selected. In mobile phase organic solvent was selected because of its favourable UV transmittance, low viscosity and provides good resolution between two drugs. The water consisting of buffer helps in obtaining sharp peaks and produces good resolution with retention time 2.1 and 3.9 min for tramadol and paracetamol respectively. The detection was carried at $228 \mathrm{~nm}$ in UV where both drugs showed good absorbance. The chromatographic analysis time was less than 8.0 min. Resolution of the two components was around 6.0 with clear baseline separation was obtained as shown in Figure 2.

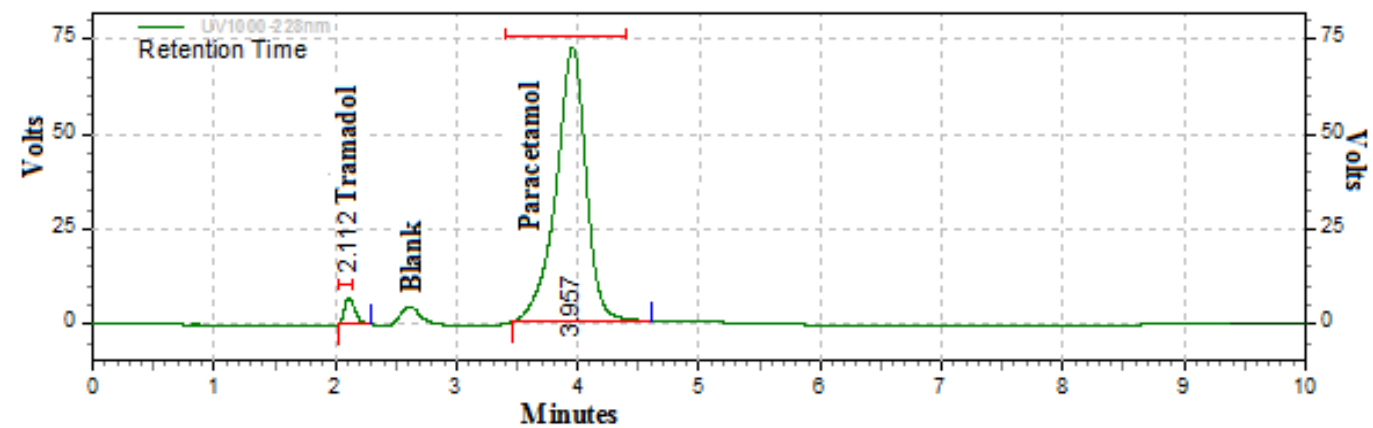

Figure 2. Typical chromatogram obtained from tramadol and paracetamol solution.

\section{Forced Degradation Studies}

In true sense, ICH guideline Q1AR and the ICH's Common Technical Document ${ }^{31}$ suggest stress testing only of the drug substance. For drug products, however, a definition and guidelines of 'Stress Testing (drug product)' is provided in $\mathrm{Q} 1 \mathrm{AR}^{32}$. In literature there exist 
many reports where stability-indicating assay has been established by carrying out stress tests directly on pharmaceutical formulations ${ }^{33-38}$.

In the present study the stress testing was carried out on paracetamol and tramadol containing pharmaceutical formulation and the degradation was observed when the analyte was subjected to acid, base, oxidation, photolytic and thermal stress conditions. The drug substances paracetamol and tramadol under acidic conditions leads to formation of an unknown degradation peaks at the retention time 4.8 and $6.5 \mathrm{~min}$ and in oxidative condition at $7.8 \mathrm{~min}$. Intentional degradation was attempted to stress conditions of acidic (using $0.1 \mathrm{~N}$ $\mathrm{HCl}$ ), basic degradation (using $0.1 \mathrm{~N} \mathrm{NaOH}$ ), oxidative degradation (using 3.0\% $\mathrm{H}_{2} \mathrm{O}_{2}$ ), photolytic degradation (UV degradation) and thermal degradation (heated at $100^{\circ} \mathrm{C}$ ) and to evaluate the ability of the proposed method to separate paracetamol, tramadol and its degradation products. Concentration of Paracetamol and tramadol $(26.0 \mu \mathrm{g} / \mathrm{ml}$ and 3.0 $\mu \mathrm{g} / \mathrm{ml}$ ) was used in all the degradation studies. After completion of the degradation processes, the solutions were neutralized and diluted with mobile phase.

Forced degradation in acidic media was performed by taking $4.0 \mathrm{ml}$ aliquot from stock solution in $50 \mathrm{ml}$ of round bottom flask, to this $5.0 \mathrm{ml}$ of $0.1 \mathrm{~N} \mathrm{HCl}$ was added and the solution was refluxed for $12 \mathrm{hrs}$ and neutralized using same strength of $0.1 \mathrm{~N} \mathrm{NaOH}$. Appropriate aliquot was taken from the above solution and diluted with mobile phase to a final concentration of 26.0 and $3.0 \mu \mathrm{g} / \mathrm{ml}$ of paracetamol and tramadol.

Forced degradation in basic media was performed by taking $4.0 \mathrm{ml}$ aliquot from stock solution in $50 \mathrm{ml}$ of round bottom flask, to this $5.0 \mathrm{ml}$ of $0.1 \mathrm{~N} \mathrm{NaOH}$ added and the solution was refluxed for $12 \mathrm{hrs}$ and neutralized using same strength of $0.1 \mathrm{~N} \mathrm{HCl}$. Appropriate aliquot was taken from the above solution and diluted with mobile phase to a final concentration of 26.0 and $3.0 \mu \mathrm{g} / \mathrm{ml}$ of paracetamol and tramadol.

Oxidative degradation was performed by taking $4.0 \mathrm{ml}$ aliquot from stock solution in 50 $\mathrm{ml}$ of round bottom flask, to this $5.0 \mathrm{ml}$ of $3 \% \mathrm{v} / \mathrm{v}$ of hydrogen peroxide added and the solution was refluxed for $12 \mathrm{hrs}$. The solution was diluted with mobile phase to obtain a final concentration of 26.0 and $3.0 \mu \mathrm{g} / \mathrm{ml}$ of paracetamol and tramadol.

To study the effect of UV light, the drug powder was exposed to light. Approximately 25 mg of tablet powder was spread on a glass dish in a layer that was less than $2 \mathrm{~mm}$ thick and was prepared in mobile phase. All samples for photostability testing were placed in a UV light cabinet and which were exposed for $12 \mathrm{hrs}$ resulting in an overall illumination of $\geq$ $210 \mathrm{Wh} / \mathrm{m}^{2}$ at $25^{\circ} \mathrm{C}$ with UV radiation. Following removal of glass dish from the UV light cabinet, all samples were prepared for analysis as previously described.

To study the effect of temperature, the tablet powder was exposed to dry heat in a controlled temperature oven at $100^{\circ} \mathrm{C}$ for $12 \mathrm{hrs}$.

\section{Stress Degradation of Formulation}

Chromatograms obtained from paracetamol and tramadol tablet solution after degradation under acidic, basic, oxidizing, photolytic and thermal conditions are shown in Figures 3- 7.

In acid ( $0.1 \mathrm{~N}$ hydrochloric acid) degradation study showed $14.52 \%$ and $32.82 \%$ degradation for tramadol and paracetamol respectively at reflux temperature after $12 \mathrm{hrs}$. A major degradation product was observed at 4.8 and $6.5 \mathrm{~min}$. 
The degradation in base $(0.1 \mathrm{~N}$ sodium hydroxide) was found to be $4.75 \%$ and $6.19 \%$ for tramadol and paracetamol respectively at reflux temperature after $12 \mathrm{hrs}$. No degradation product was observed.

Oxidative degradation study in 3\% hydrogen peroxide gave around $4.74 \%$ and $1.15 \%$ degradants at reflux temperature at end of $12 \mathrm{hrs}$. A degradation product was observed at 7.8 min.

In photolytic, UV degradation the drug degraded was $2.24 \%$ and $0.65 \%$ of tramadol and paracetamol for $12 \mathrm{hrs}$. No degradation peak was obtained.

The thermal study was carried out by exposure of tablet powder to dry heat at $100^{\circ} \mathrm{C}$ for $12 \mathrm{hrs}$. There were no degradation peak observed in chromatogram and degradation was $6.50 \%$ and $1.68 \%$ for tramadol and paracetamol respectively.

The results from force degradation studies are summarized in Table 1.

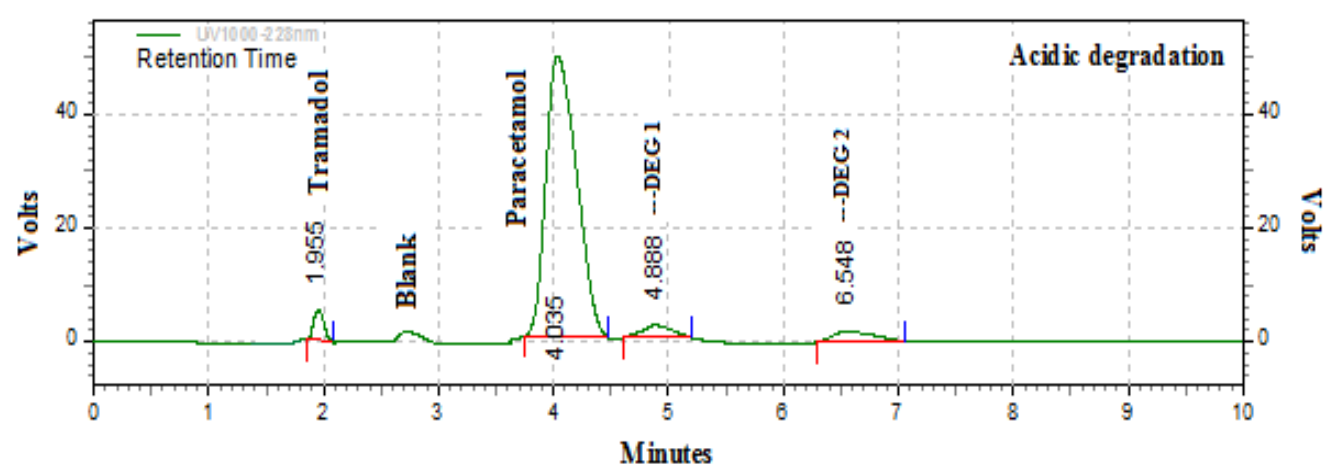

Figure 3. Representative chromatogram obtained from Acidic degradation $(0.1 \mathrm{~N} \mathrm{HCl})$.

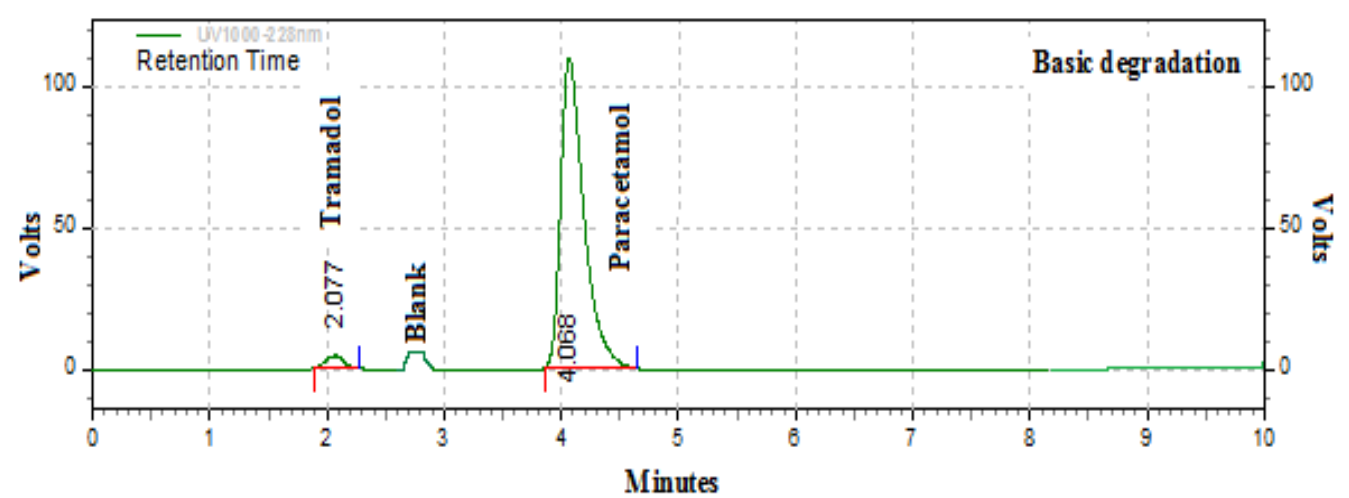

Figure 4. Representative chromatogram obtained from Basic degradation $(0.1 \mathrm{~N} \mathrm{NaOH})$. 


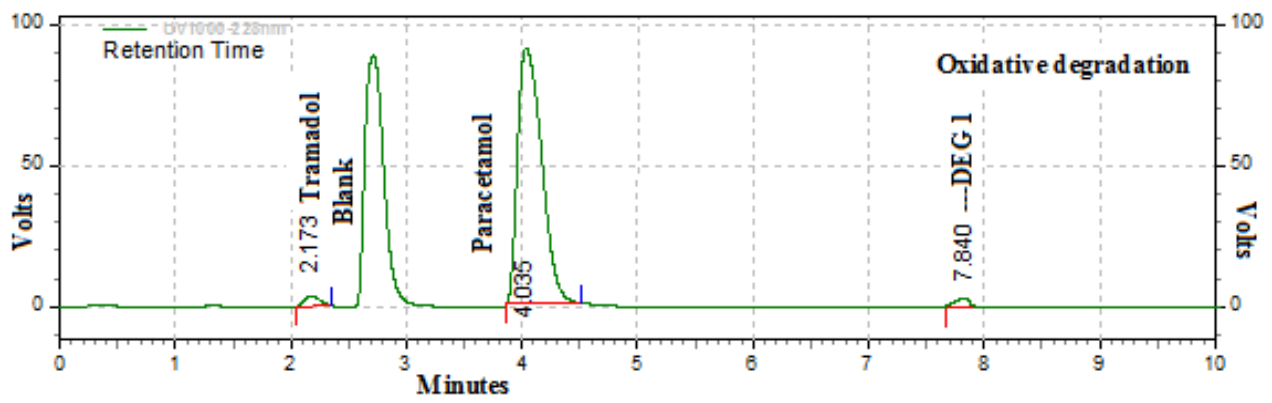

Figure 5. Representative chromatogram obtained from oxidative degradation $\left(3 \% \mathrm{H}_{2} \mathrm{O}_{2}\right)$.

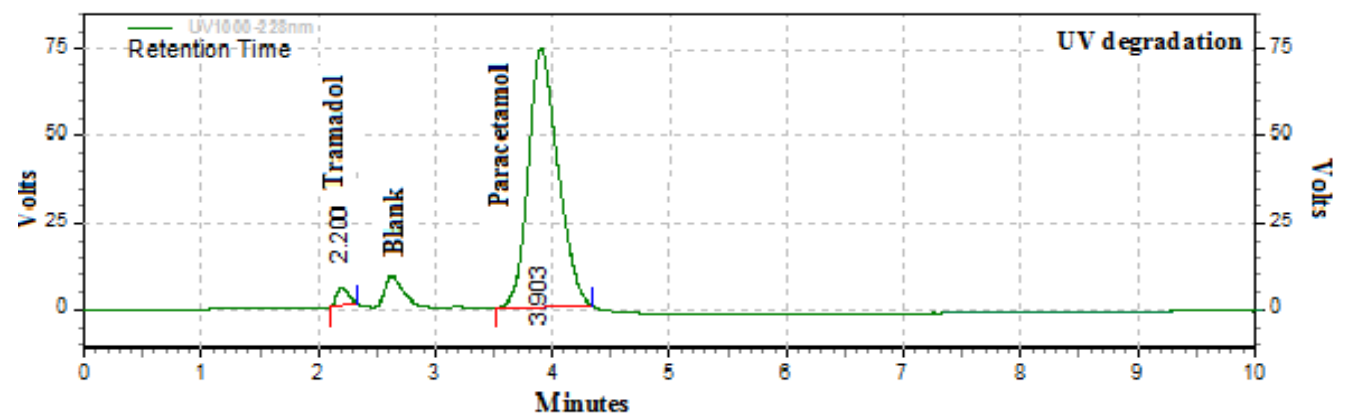

Figure 6. Representative chromatogram obtained from UV radiation in UV light cabinet.

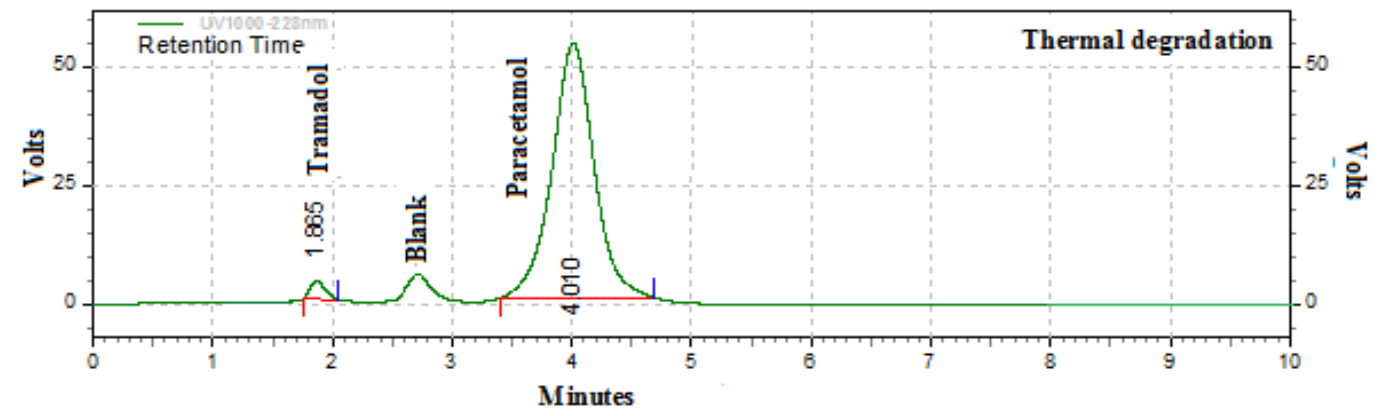

Figure 7. Representative chromatogram obtained from thermal degradation at $100^{\circ} \mathrm{C}$.

\section{Method Validation}

The test method was validated for specificity, linearity, precision, accuracy, range, stability of sample solution and robustness were found to be meeting the predetermined acceptance criteria. The validated method was found to be specific, linear, precise, accurate and robust for the assay of paracetamol and tramadol in their tablet dose form. Hence, this method can be introduced into the use for the assay of paracetamol and tramadol in tablets. 
Table 1. Results from analysis of samples from the forced degradation study.

\begin{tabular}{|c|c|c|c|c|c|c|c|c|}
\hline \multirow{2}{*}{$\begin{array}{l}\text { Stress } \\
\text { condition }\end{array}$} & \multirow[t]{2}{*}{ Time } & \multicolumn{4}{|c|}{ Tramadol } & \multicolumn{2}{|c|}{ Paracetamol } & \multirow[t]{2}{*}{ Remarks } \\
\hline & & $\begin{array}{l}\text { Ret. } \\
\text { time }\end{array}$ & $\begin{array}{c}\% \\
\mathrm{RS} \\
\mathrm{D}\end{array}$ & $\begin{array}{c}\% \\
\text { Degrd. }\end{array}$ & $\begin{array}{l}\text { Ret. } \\
\text { time }\end{array}$ & $\begin{array}{c}\% \\
\mathrm{RS} \\
\mathrm{D}\end{array}$ & $\begin{array}{c}\% \\
\text { Degrd. }\end{array}$ & \\
\hline $\begin{array}{l}\text { Acid } \\
\text { degradation }\end{array}$ & $12 \mathrm{hrs}$ & 1.95 & 0.41 & 14.52 & 4.03 & 0.62 & 32.82 & $\begin{array}{l}\text { Significant } \\
\text { degradation } \\
\text { product found at } \\
4.8 \text { and } 6.5 \mathrm{~min}\end{array}$ \\
\hline $\begin{array}{l}\text { Basic } \\
\text { degradation }\end{array}$ & $12 \mathrm{hrs}$ & 2.07 & 0.79 & 4.75 & 4.06 & 0.35 & 6.19 & $\begin{array}{l}\text { No degradation } \\
\text { product formed }\end{array}$ \\
\hline $\begin{array}{l}\text { Oxidative } \\
\text { degradation }\end{array}$ & $12 \mathrm{hrs}$ & 2.18 & 0.78 & 4.74 & 4.00 & 0.48 & 1.15 & $\begin{array}{l}\text { Significant } \\
\text { degradation } \\
\text { product found at } \\
7.8 \mathrm{~min}\end{array}$ \\
\hline $\begin{array}{l}\text { UV } \\
\text { degradation }\end{array}$ & $12 \mathrm{hrs}$ & 2.20 & 0.76 & 2.24 & 3.90 & 0.67 & 0.65 & $\begin{array}{l}\text { No degradation } \\
\text { product formed }\end{array}$ \\
\hline $\begin{array}{l}\text { Thermal } \\
\text { degradation }\end{array}$ & $12 \mathrm{hrs}$ & 1.88 & 0.32 & 6.50 & 4.01 & 0.39 & 1.68 & $\begin{array}{l}\text { No degradation } \\
\text { product formed }\end{array}$ \\
\hline
\end{tabular}

Precision, as \% RSD evaluated from the area of paracetamol and tramadol peaks from six replicated injections of standard solution indicating that the measurement system was precise for the determination of paracetamol and tramadol in tablets. Also, \% RSD of intraday and interday precisions of the proposed method was determined by estimating the corresponding responses 6 times on the same day and 6 on another day for same concentration of paracetamol $(26.0 \mu \mathrm{g} / \mathrm{ml})$ and tramadol $(3.0 \mu \mathrm{g} / \mathrm{ml})$. The $\%$ RSD for both intraday and interday was not more than $2.0 \%$.

The accuracy of the method was studied by measuring of recovery after standard addition method of paracetamol and tramadol at 80, 100, 120 and 150\% level. Known amounts of standard solutions of paracetamol $(20.8,26.0,31.2$ and $39.0 \mu \mathrm{g} / \mathrm{ml})$ and tramadol $(2.4,3.0$, 3.6 and $4.5 \mu \mathrm{g} / \mathrm{ml}$ ) were spiked to prequantified sample solutions. The percent recoveries obtained were between 98.0 to $102 \%$ for both samples. These high values indicate that the method is accurate.

Linearity, the value of correlation coefficient obtained from the linearity studies (correlation coefficient for paracetamol was 0.99986 and for Tramadol was 0.99974) indicating that the response was linear for paracetamol and Tramadol peaks over the concentration range from $20.8-39.0 \mu \mathrm{g} / \mathrm{ml}$ for paracetamol and $2.4-4.5 \mu \mathrm{g} / \mathrm{ml}$ for Tramadol. A calibration curve for each sample was obtained by plotting area response versus concentration which gave a straight line corresponding to the equation: $y=m x+c$. The results showed that good correlation existed between the park area and concentration of the analytes. 
In the system suitability test of solution containing $26.0 \mu \mathrm{g} / \mathrm{ml}$ of paracetamol and 3.0 $\mu \mathrm{g} / \mathrm{ml}$ of tramadol were prepared and injected six times $(\mathrm{n}=6)$. The standard and sample solutions were stored at room temperature and analyzed over the time period of $0 \mathrm{hrs}, 12 \mathrm{hrs}$ and $24 \mathrm{hrs}$. Then different parameters such as retention time, theoretical plates, tailing factor and resolution were calculated from the obtained chromatograms. Thus absolute difference between $\%$ assay values was not more than $\pm 2.0 \%$ compared to the initial values which were in agreement with the USP requirements. Results from validation are presented in Table 2.

Table 2. Results from Validation of method.

\begin{tabular}{lrlc}
\hline Parameter & & Paracetamol & Tramadol \\
\hline Linearity coefficient & & & 0.99974 \\
Precision & \%RSD & 0.16 & 0.19 \\
Intermediate Precision & \% RSD & 0.20 & 0.25 \\
Solution stability $\quad$ \% RSD 12 hrs & 0.25 & 0.11 \\
& \% RSD 24 hrs & 0.17 & 0.36 \\
Retention times & Minutes & 3.9 & 2.1 \\
Resolution & & 6.07 & --- \\
\hline
\end{tabular}

Table 3. Results from robustness testing.

\begin{tabular}{lrrrrrr}
\hline $\begin{array}{l}\text { Chromatographic } \\
\text { change factor }\end{array}$ & \multicolumn{2}{c}{ Variation } & \multicolumn{2}{c}{ Paracetamol } & \multicolumn{2}{c}{ Tramadol } \\
\cline { 4 - 7 } & & & $\begin{array}{l}\text { Ret. } \\
\text { time }\end{array}$ & $\begin{array}{c}(\%) \\
\text { RSD }\end{array}$ & $\begin{array}{c}\text { Ret. } \\
\text { time }\end{array}$ & $\begin{array}{c}(\%) \\
\text { RSD }\end{array}$ \\
\hline \multirow{2}{*}{ Flow rate (ml/min) } & 0.8 & -0.2 & 4.82 & 0.42 & 2.68 & 0.28 \\
& 1.0 & 0.0 & 3.90 & 0.10 & 2.19 & 0.14 \\
& 1.2 & +0.2 & 3.23 & 0.43 & 1.79 & 0.41 \\
Wavelength (nm) & 226 & -0.2 & 3.88 & 0.38 & 2.16 & 0.33 \\
& 228 & 0.0 & 3.89 & 0.13 & 2.18 & 0.16 \\
& 230 & +0.2 & 3.60 & 0.36 & 2.14 & 0.32 \\
Mobile phase & $38: 62$ & -0.2 & 4.01 & 0.50 & 2.23 & 0.31 \\
(Methanol: Buffer) & $40: 60$ & 0.0 & 3.89 & 0.19 & 2.19 & 0.28 \\
& $42: 58$ & +0.2 & 3.74 & 0.32 & 2.09 & 0.81 \\
\hline
\end{tabular}


As recommended in the ICH guidelines, a robustness assessment was performed during the development of the analytical procedure. The robustness of the method was investigated under a variety of conditions including slightly changes of flow rate $(1.0 \pm 0.2 \mathrm{ml} / \mathrm{min})$, change in detection wavelength ( $228 \pm 2.0 \mathrm{~nm}$ ), change in composition of mobile phase methanol : buffer $(38: 62,40: 60,42: 58)$. One factor at a time was changed to estimate the effect. The degree of reproducibility of the results obtained as a result of small deliberate variations in the method parameters has proven that the method is robust and the data is summarized in Table 3.

\section{Conclusion}

The method developed for quantitative analysis of paracetamol and tramadol is rapid, accurate, precise, selective and reproducible. The method was completely validated and satisfactory results were obtained for all the characteristics tested. The major degradation was obtained in acidic and minor in basic, thermal, oxidative and photolytic stress conditions. The forced degradation studies prove the stability indicating power of the method and can be used to assess the stability of paracetamol and tramadol in the bulk drug and in pharmaceutical dosage forms. The method can be conveniently used for assay of the pharmaceutical dosage forms containing paracetamol and tramadol in quality control laboratory.

\section{References}

1. Singh S, Singh B, Bahuguna R, Wadhwal L and Saxena R, J. Pharma Biomed. Anal., 2006, 41, 1037-1040.

2. Mohammadi A, Haririan I, Rezanour N, Ghiasi L and Walker R B, J. Chromatogr. A, 2006, 1116, 153-157.

3. Ivana I, Ljiljana Z and Mira Z, J Chromatogr. A, 2006, 1119, 209-215.

4. International Conference on Harmonization, Q1A (R2) Stability Testing of New Drug Substances and Products International Conference on Hormonization, IFPMA, Geneva, 2003.

5. Satoskar R S, Bandarkar S D and Ainapare S S, Pharmacology and Pharmacotherapeutics., $16^{\text {th }}$ ed., Popular prakashan, Mumbai, 1999, 164.

6. Indian Pharmacopoeia Vol III. Published by The Indian pharmacopoeia commission, Ghaziabad, 2007, 1516.

7. Grosa G, Grosso E D, Russo R and Allegrone G, J. Pharma Biomed. Anal., 2006, 41, 798-803.

8. Lintz W., Barth H, Osterloh G and Schmidt-Bothelt E, Drug Res., 1998, 48, 889-899.

9. Krzek J and Starek M, Biomed. Chromatogr., 2004, 18, 589-599.

10. Kartinasari W F, Palupi T and Indrayanto G, J. Liq. Chromatogr. Related Tech., 27, 2004, 737-744.

11. Wiwin F K, Tini P and Gunawan I, J. Liq. Chromatogr. Related Tech., 2005, 27, 737-744.

12. Yalda H A, Faezeh S H, Aboul-Enein Y and Alireza F, J. Chromatogr. B, 2006, 830, 207-211.

13. Rajasekhar K K, Shankarananth V, Jyosthna P, Chowdary S P and Reddy D P, J. Pharm. Res., 2011, 4, 386-387.

14. Morelli B and Gowda K, J. Pharm Biomed Anal., 1989, 7, 577-584.

15. Lau G S N and Critchley J A J H, J. Pharm. Biomed. Anal., 1994, 12, 1563-1572. 
16. Bosch M E, Ruiz Sanchez A J, Sanchez Rojas F and Bosch Ojeda C, J. Pharm. Biomed. Anal., 2006, 42, 291-321.

17. Lakshminarayan K V, Ind. J. Pharm. Sci., 2007, 69, 147-149.

18. Sawant R, Bhangale L, Josh R and Lanke P, J. Chem. Metrol., 2010, 4, 21-27.

19. Gharge D, and Dhabale P, Int. J. Chem. Anal. Sci., 2010, 1, 58-61.

20. Srinivasan K K, Alex J, Shirwaikar A A, Jacob S, Sunil Kumar M R and Prabu S L, Indian J. Pharm. Sci., 2007, 69, 540-545.

21. Zhu T, Ding L, Guo X, Yang L and Wen A, Chromatographia, 2007, 66, 171-178.

22. Tan Z, Ouyang D, Zhou G, Wang L, Li Z, Wang D, Chen G, Huang S, Liu Y, Hu D and Zhou H, Yaowu Fenxi Zazhi, 2005, 25, 795-798.

23. Li Y, Wan X, Wang G and Cui J, Zhongguo Yaoxue Zazhi (Beijing, China), 2006, 41, 1594-1595.

24. Narayan S, Kumar P, Sindhu R K, Tiwari A and Ghosh M, Der Pharma Chemica, 2009, 1, 72-78.

25. Mary Titus J F, Thenmozhi A, Sridharan D and Palanivelu M, Int. J. Pharma Recent Res. 2009, 1, 22-26.

26. Sam Soloman W D, Vijai Anand P R, Shukla R, Sivakumar R and Venkatnarayanan R, Int. J. Chem. Tech. Res., 2010, 2, 1188-1193.

27. Belal T, Awad T and Clark C R, J. Chromatogr. Sci., 2009, 47, 849-854.

28. Liu X, Shi J, Liu Y and He Z, Shenyang Yaoke Daxue Xuebao, 2004, 21, 111-113.

29. Birajdar A S, Meyyanathan S N and Suresh B, Int. J. Pharmaceuit. Res. Devp., 2010, 1, 1-6

30. Kalra K, Naik S, Jarmal G and Mishra N, Int. J. Appl. Chem., 2009, 5, 73-76.

31. ICH, The Common Technical Document- QUALITY. International Conference on Hormonisation, IFPMA, Geneva, 2000

32. ICH, Stability Testing of New Drug Substances and Products. International Conference on Hormanisation, IFPMA, Geneva, 2000, p.17

33. Garnick R L, Burt G F, Long D A, Bastian J W and Aldred J P, J. Pharm. Sci., 1984, 73, 75-77.

34. Boulton D W, Fawcett J P and Woods D J, Am. J. Health-Syst. Pharm., 1996, 53, $1157-1161$.

35. Montgomery E R, Taylor S, Segretario J, Engler E and Sebastian D, J. Pharm. Biomed. Anal., 1996, 15, 73-82.

36. Zhao Z, Wang Q, Tsai E W, Qin X-Z and Ip D, J. Pharm. Biomed. Anal., 1999, 20, $129-136$.

37. Kachhadia P K, Doshi A S, Ram V R and Joshi H S, Chromatographia, 2008, 68, 997-1001.

38. Shabir G A and Arain S A, J. Liq. Chromatogr. Related Tech., 2011, 34, 719-729. 


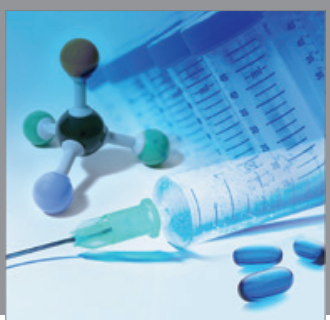

International Journal of

Medicinal Chemistry

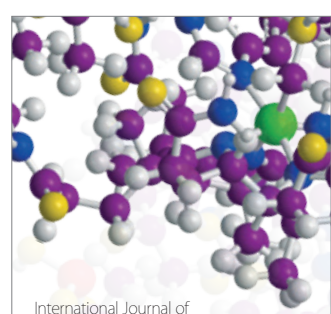

Carbohydrate Chemistry

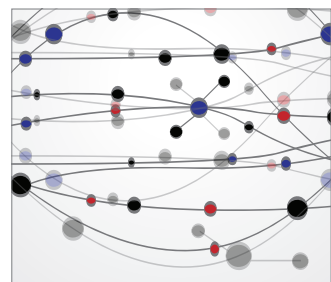

The Scientific World Journal
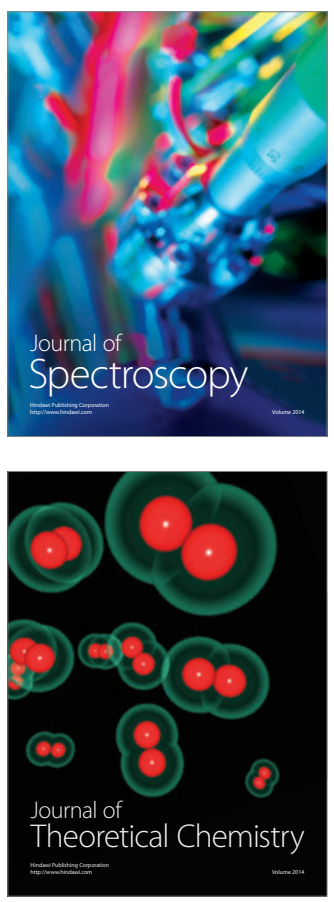
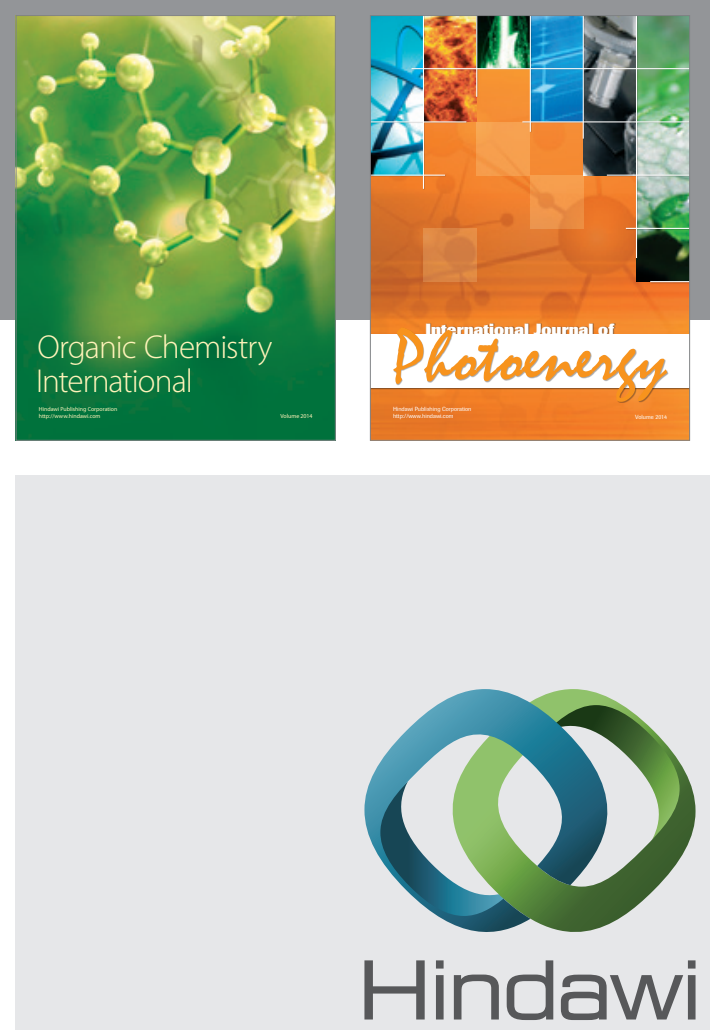

Submit your manuscripts at

http://www.hindawi.com
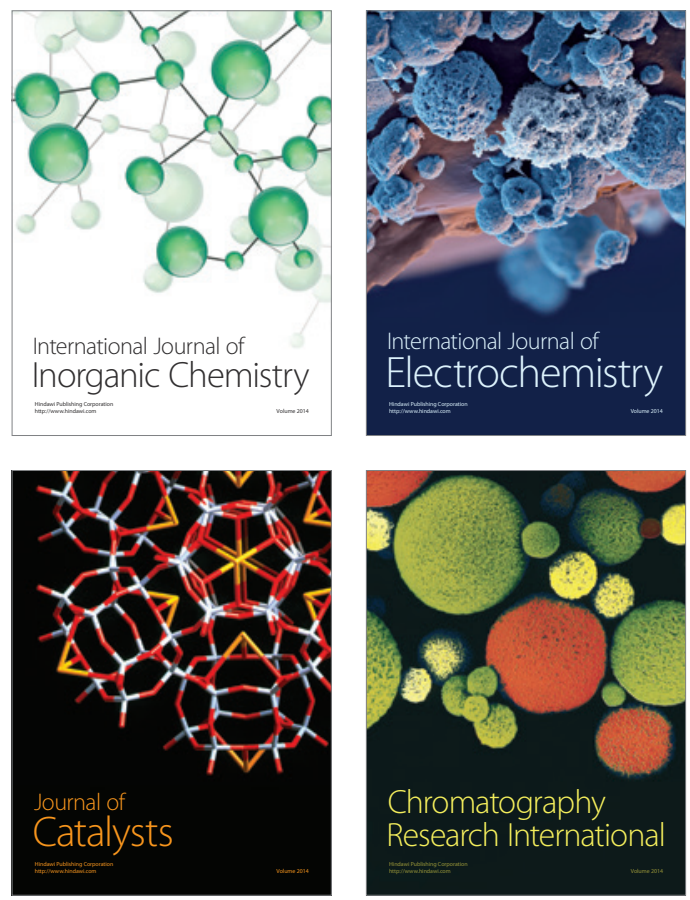
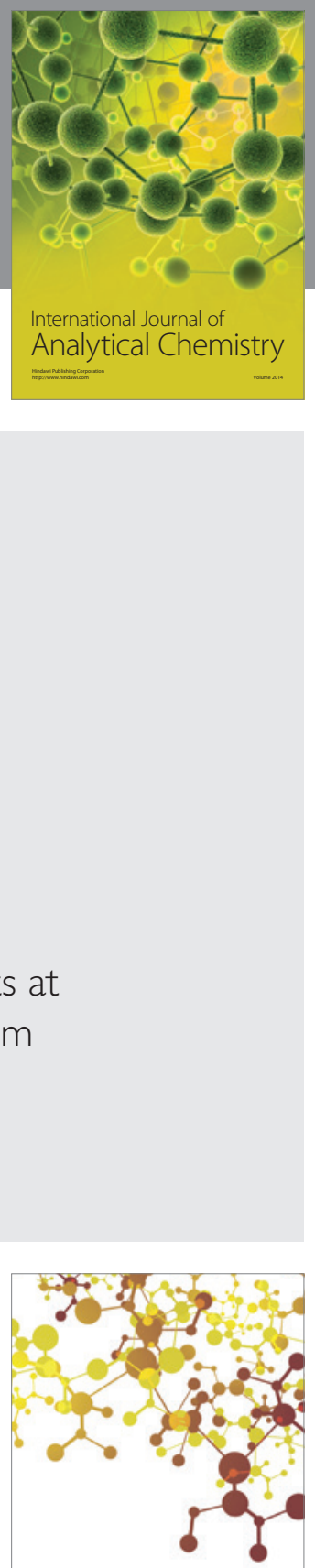

Journal of

Applied Chemistry
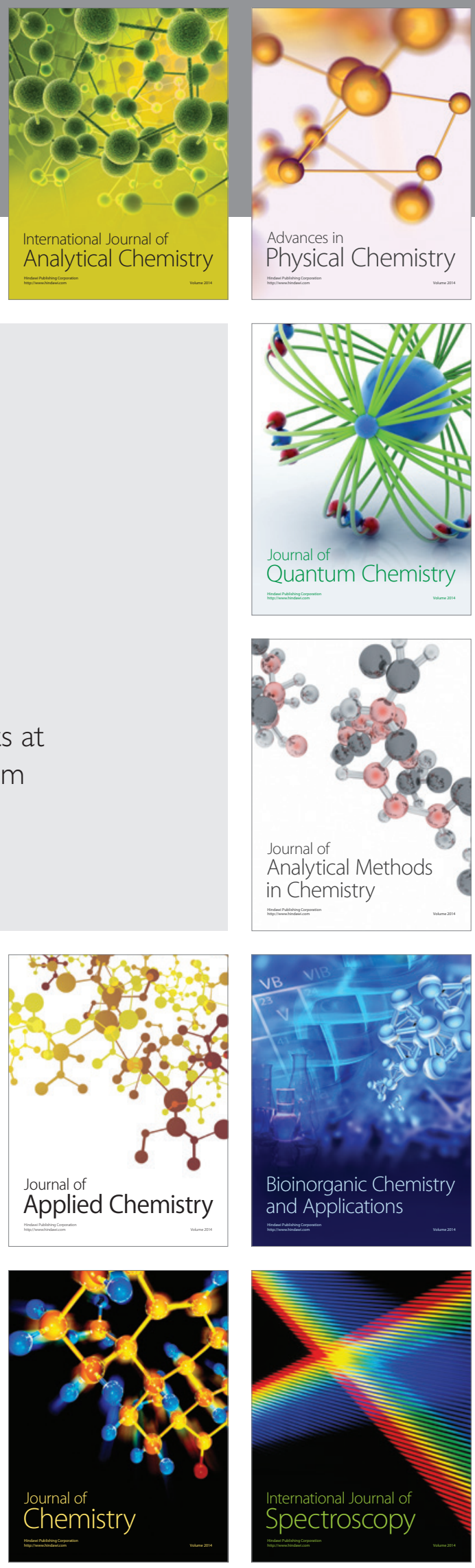